\title{
Epigenetic Regulation of Hippocampal Fosb Expression Controls Behavioral Responses to Cocaine
}

\author{
Paula A. Gajewski, ${ }^{1}$ DAndrew L. Eagle, ${ }^{1}$ Elizabeth S. Williams, ${ }^{1}$ Claire E. Manning, ${ }^{1}$ Haley Lynch, ${ }^{1}$ Colin McCornack, ${ }^{1}$ \\ Ian Maze, ${ }^{2}$ Elizabeth A. Heller, ${ }^{3}$ and A.J. Robison ${ }^{1}$ \\ ${ }^{1}$ Department of Physiology, Michigan State University, East Lansing, Michigan 48824, ${ }^{2}$ Department of Pharmacology and Systems Therapeutics, Icahn \\ School of Medicine at Mount Sinai, New York, New York 10029, and '3Department of Systems Pharmacology and Translational Therapeutics, University of \\ Pennsylvania, Philadelphia, Pennsylvania 19104
}

Drug addiction results in part from maladaptive learning, including the formation of strong associations between the drug and the circumstances of consumption. However, drug-induced changes in gene expression underlying the saliency of these associations remain understudied. Consolidation of explicit memories occurs within the hippocampus, and we have shown that spatial learning induces expression of the transcription factor $\Delta$ FosB in hippocampus and that this induction is critical for learning. Drugs of abuse also upregulate $\Delta$ FosB in hippocampus, but the mechanism of its induction by cocaine and its role in hippocampus-dependent cocaine responses is unknown. We investigated differences in mouse dorsal and ventral hippocampal $\Delta$ FosB expression in response to chronic cocaine, because these regions appear to regulate distinct cocaine-related behaviors. We found that cocaine-mediated induction of $\Delta$ FosB was subregion-specific, and that $\Delta$ FosB transcriptional activity in both the dorsal and ventral hippocampus is necessary for cocaine conditioned place preference. Further, we characterize changes in histone modifications at the Fos $B$ promoter in hippocampus in response to chronic cocaine and found that locus-specific epigenetic modification is essential for Fos $B$ induction and multiple hippocampusdependent behaviors, including cocaine place preference. Collectively, these findings suggest that exposure to cocaine induces histone modification at the hippocampal FosB gene promoter to cause $\Delta$ FosB induction critical for cocaine-related learning.

Key words: $\Delta \mathrm{FosB}$; cocaine; epigenetics; hippocampus; histone; transcription

Significance Statement

Although cocaine addiction is driven in part by the formation of indelible associations between the drug and the environment, paraphernalia, and circumstances of use, and although this type of associative learning is dependent upon changes in gene expression in a brain region called the hippocampus, the mechanisms by which cocaine alters hippocampal gene expression to drive formation of these associations is poorly understood. Here, we demonstrate that chronic cocaine engages locus-specific changes in the epigenetic profile of the FosB gene in the hippocampus, and that these alterations are required for cocainedependent gene expression and cocaine- environment associations. This work provides novel insight into addiction etiology and potential inroads for therapeutic intervention in cocaine addiction.

\section{Introduction}

The hippocampus is essential for the formation of drug-related memories, specifically drug-environment associations, and the establishment of these associations requires differential activa-

\footnotetext{
Received April 9, 2019; revised Aug. 8, 2019; accepted Aug. 13, 2019.

Author contributions: P.A.G., I.M., E.A.H., and A.J.R. designed research; P.A.G., A.L.E., E.S.W., C.E.M., H.L., C.M., I.M., and A.J.R. performed research; E.A.H. contributed unpublished reagents/analytic tools; P.A.G. and A.J.R. analyzed data; P.A.G. and A.J.R. wrote the paper.

This work was supported by NIMH R01 MH111604 and NIDA R01 DA040621. We thank Ken Moon for outstanding technical support and Dr. Michelle Mazei-Robison for manuscript advice and editing.

The authors declare no competing financial interests.

Correspondence should be addressed to A.J. Robison at robis045@msu.edu.

https://doi.org/10.1523/JNEUROSCI.0800-19.2019

Copyright $\odot 2019$ the authors
}

tion of the dorsal and ventral regions of the hippocampus (Robbins et al., 2008). The distinct functions of these regions appear to underlie multiple aspects of addiction, like relapse and reward, which can be modeled in rodents. Chronic exposure to cocaine alters the function of hippocampal cells, including plasticity of hippocampal synapses (Thompson et al., 2002; Perez et al., 2010; Adinoff et al., 2015). This plasticity requires active changes in chromatin structure and gene transcription (Walton et al., 1999; Kennedy et al., 2016; McEwen, 2016), and exposure to cocaine leads to the differential expression of hundreds of genes in the hippocampus (Krasnova et al., 2008). Many previous studies have focused on cocaine-mediated epigenetic changes in the nucleus accumbens (NAc), a component of the brain's reward cir- 
cuitry, and have identified numerous changes in expression and function of histone modifying enzymes, such as histone deacetylases and histone methyltransferases (Kalda and Zharkovsky, 2015; Walker et al., 2015). One in particular, a lysine dimethyltransferase called G9a, is decreased in NAc by repeated cocaine exposure leading to a decrease in the repressive histone modification, lysine 9 dimethylation of histone $\mathrm{H} 3$ (H3K9me2), and this decrease is necessary for plasticity changes in the NAc and subsequent cocaine-related behavior (Maze et al., 2010b; Benevento et al., 2015). Similarly, epigenetic modifications are also important for maintaining normal hippocampal function and plasticity (Sweatt, 2013; Srivas and Thakur, 2017), indicating a potential mechanism by which cocaine may cause changes in plasticityrelated hippocampal gene expression. Thus, to delineate the cocaine-dependent changes in hippocampal cell function that may underlie critical aspects of addiction we must determine the hippocampal transcriptional and epigenetic factors engaged by cocaine and their effects on drug responses.

Chronic exposure to drugs of abuse evokes long-lasting changes in synaptic morphology and function in the hippocampus (Keralapurath et al., 2014), implicating persistent regulation of gene expression. $\Delta$ FosB is a stable transcription factor induced by chronic stimuli and studied extensively in the context of addiction (Robison and Nestler, 2011). $\Delta$ FosB is a splice variant originating from the Fos $B$ gene but lacking two degron domains, making it uniquely resistant to proteolysis, with a half-life of up to $8 \mathrm{~d}$ in the brain (Ulery-Reynolds et al., 2009). $\Delta \mathrm{FosB}$ is induced in many brain regions in response to chronic stimuli, including drugs of abuse (Perrotti et al., 2008), and the mechanism of its induction in the NAc has recently focused on changes in epigenetic factors, specifically H3K9me2 by G9a (Núñez et al., 2010; Damez-Werno et al., 2012; Heller et al., 2014; Hamilton et al., 2018). Additionally, much of what we know about the target genes of $\Delta$ FosB comes from addiction and depression studies in the NAc, and many of those NAc target genes, such as CaMKII $\alpha$, GluA2, and Cdk5 (Kelz et al., 1999; Chen et al., 2000; Robison et al., 2013), regulate synaptic plasticity in the hippocampus. Though it has long been known that $\Delta$ FosB is induced in dorsal hippocampus by chronic exposure to drugs or stress (Perrotti et al., 2004, 2008), its critical role in hippocampal synaptic structure and spatial learning were only recently reported (Eagle et al., 2015). Here, we investigate the epigenetic mechanism of $\Delta$ FosB induction in hippocampus by cocaine and the role of hippocampal $\Delta$ FosB in cocaine reward. Our results provide novel insight into cocaine-mediated epigenetic and transcriptional changes in the hippocampus and how those changes regulate drug-related memories and behaviors, indicating the potential for targeting hippocampal epigenetic and transcriptional mechanisms in the treatment of addiction.

\section{Materials and Methods}

Animals. Male 7-week-old C57BL/6J mice were group housed 4-5 per cage in a $12 \mathrm{~h}$ light/dark cycle and were provided food and water ad libitum. All experiments were approved by the Institutional Animal Care and Use Committee at Michigan State University. For chromatin immunoprecipitation (ChIP), immunohistochemistry, and Western blot experiments, mice received daily intraperitoneal (i.p.) injections of either saline or cocaine $(20 \mathrm{mg} / \mathrm{kg}$ ) and were placed into a novel environment (1 chamber of a conditioned place preference apparatus from San Diego Instruments) for $30 \mathrm{~min}$ for 10 consecutive days, and were killed 1 or $24 \mathrm{~h}$ after the last injection (ChIP, qRT-PCR, Western blot: $1 \mathrm{~h}$; immunohistochemistry: $24 \mathrm{~h}$ ). Additionally, $30-40 \mathrm{~min}$ before any behavioral assay took place, mice were placed into the behavioral room to habituate to the environment. Open field, novel object recognition, and contextual fear conditioning were performed in battery in that order over $5 \mathrm{~d}$. All other behavioral experiments were performed on individual cohorts of mice.

Surgery. Stereotaxic surgery was performed to inject viral vectors into the dorsal or ventral hippocampus of adult male mice. Thirty gauge needles (Hamilton) were bilaterally placed at the following coordinates for dorsal hippocampus: $10^{\circ}$ angle, $-2.2 \mathrm{~mm}$ anteroposterior (AP), \pm 2.5 $\mathrm{mm}$ mediolateral, virus was infused $(0.6 \mu \mathrm{l})$ separately $(0.3 \mu \mathrm{l} /$ infusion $)$ over 3 min periods at two sites: $-2.1 \mathrm{~mm}$ dorsoventral (DV) and -1.9 $\mathrm{mm}$ DV; coordinates for ventral hippocampus: $3^{\circ}$ angle, $-3.2 \mathrm{~mm} \mathrm{AP}, \pm$ $3.4 \mathrm{~mm}$ mediolateral, virus was infused $(0.5 \mu \mathrm{l})$ over $5 \mathrm{~min}$ period at one site: $-4.8 \mathrm{DV}$. After infusion, the needles remained at the injection site for $5 \mathrm{~min}$ to allow for diffusion of the viral particles. Previously validated (Robison et al., 2013; Heller et al., 2014) viral vectors included the following: herpes simplex virus (HSV) expressing GFP alone (HSV-GFP), HSV expressing GFP and $\Delta$ JunD (HSV- $\Delta$ JunD), or HSV expressing GFP and FosB-ZFP-G9a (HSV-FosB-ZFP-G9a); adeno-associated virus (AAV) expressing GFP alone (AAV-GFP) or AAV expressing GFP and $\Delta$ JunD (AAV- $\Delta$ JunD). HSVs were obtained from the Massachusetts Institute of Technology Viral Core Facility (now located at Massachusetts General Hospital) and AAVs were obtained from the University of North Carolina Vector Core. Location of injection sites were confirmed using perfusion, brain slicing, and postmortem GFP fluorescence following behavioral analyses. Animals lacking clear GFP fluorescence bilaterally in the target regions were excluded from analysis (n.b., this is the reason for different group sizes in some experiments).

Open-field activity. Animals were placed in an open box as previously described (Eagle et al., 2015) and tested for $60 \mathrm{~min}$, which occurred $48 \mathrm{~h}$ after stereotaxic surgery. Activity was recorded with a digital CCD camera connected to a computer running automated video tracking software package (Clever Sys). Time spent within the center of the box (the center starts $\sim 9.5 \mathrm{~cm}$ from the edge of the wall) and distance moved were measured.

Novel object recognition. Novel object recognition (NOR) was assessed using a 3-d paradigm as described previously (Eagle et al., 2015) on the same cohort that underwent open-field (OF) analysis. Briefly, mice which were first habituated to the OF apparatus (see above method), were exposed to two identical objects placed in opposite corners of the OF box $24 \mathrm{~h}$ later and were allowed to explore the apparatus for $30 \mathrm{~min}$. Four hours (see Fig. 5D, Short-Term) or 24 hours (all other figures) after initial exposure to the objects, one object was removed and replaced with another dissimilar object, and mice were allowed to freely explore the apparatus for $5 \mathrm{~min}$. Time spent with the objects was scored by a blind observer. Object investigation was defined as the nose of the mouse pointing toward the object when the mouse was no $>1 \mathrm{~cm}$ away. Automated video tracking software (Clever Sys) was used to analyze total distance moved over the course of the 5 min exploration.

Contextual fear conditioning. Contextual fear conditioning (CFC) consisted of a $2 \mathrm{~d}$ procedure as described previously (Eagle et al., 2015). The conditioning portion took place in the afternoon following the NOR test (thus, the same cohort of mice were used for OF, NOR, and CFC). For conditioning, mice were placed into an operant chamber for a total of 6 min. Three mild electric footshocks $(0.8 \mathrm{~mA}, 1 \mathrm{~s}$ duration), each separated by a $60 \mathrm{~s}$ interval, were administered. Twenty-four hours after conditioning, mice were placed back into the conditioning chamber for 8 min. The percentage of time spent freezing was video scored by a blind, independent observer. Freezing was defined as the lack of skeletal movement for periods $>1 \mathrm{~s}$. Data were analyzed as total time spent freezing (displayed in figures) as well as in 1 min individual blocks across the assay. Groups did not differ in either method of analysis.

Elevated plus maze. Elevated plus maze (EPM) behavior was performed as previously described (Eagle et al., 2015). Briefly, $48 \mathrm{~h}$ after stereotaxic surgery mice were placed into the center of the maze facing an open arm and behavior was video recorded for $5 \mathrm{~min}$. The percentage of time spent in the open arms and the percentage of entries into the open arms were quantified using the automated video tracking software (Clever Sys).

Cocaine conditioned place preference. Conditioned place preference (CPP) consisted of a $4 \mathrm{~d}$ protocol as previously described (Iñiguez et al., 
2015). Briefly, mice were evaluated for cocaine place preference using three-chambered CPP San Diego Instrument boxes and software. The mice were placed into the three-compartment apparatus on preconditioning day and allowed to freely explore all three chambers for $15 \mathrm{~min}$ to obtain baseline preference. The preconditioning trial took place 1-2 d before any stereotaxic surgery to eliminate any stress-evoked biases. Groups were balanced and adjusted for any pre-existing chamber bias, such that total preference for each group was very close to zero before conditioning. Conditioning trials ( $30 \mathrm{~min}, 2$ per day) were given on 2 consecutive days and began $48 \mathrm{~h}$ after stereotaxic surgery. During the conditioning trials mice received an intraperitoneal injection of saline in the morning and were confined to one chamber for $30 \mathrm{~min}$. Four hours later mice received an intraperitoneal injection of cocaine $(5 \mathrm{mg} / \mathrm{kg})$ and were confined to the opposite chamber for $30 \mathrm{~min}$. On test day, which took place $24 \mathrm{~h}$ after the last conditioning trail, mice were allowed to freely explore all three chambers for $15 \mathrm{~min}$ and amount of time spent in each chamber was recorded and used to assess preference. Data were captured by recording movements with a $4 \times 6$ photobeam array and analyzed using PAS software and the Place Preference Reporter.

Immunohistochemical assay for FosB. After $10 \mathrm{~d}$ of chronic cocaine (or saline) treatment (see Animals section in Materials and Methods), mice were perfused transcardially with ice-cold PBS followed by $10 \%$ formalin $24 \mathrm{~h}$ after the last injection. Brains were postfixed $24 \mathrm{~h}$ in $10 \%$ formalin, cryopreserved in $30 \%$ sucrose, and then sliced into $35 \mu \mathrm{m}$ sections. Immunohistochemistry was performed using rabbit anti-FosB primary antibody [1:500; FosB (5G4); Cell Signaling Technology, 2251S], and biotinylated goat anti-rabbit secondary (1:1000; BA-1000, Vector Laboratories), and visualized by 3,3' -diaminobenzidine staining (Vector Laboratories).

Immunofluorescence for FosB. Mice were perfused transcardially with ice-cold PBS followed by $10 \%$ formalin. Brains were postfixed for $24 \mathrm{~h}$ in $10 \%$ formalin and cryopreserved in $30 \%$ sucrose overnight, and then sliced into $35 \mu \mathrm{m}$ sections. Immunofluorescence was performed using anti-FosB primary antibody [FosB (5G4), 1:1000; Cell Signaling Technology, 2251S] and corresponding secondary antibody (Donkey antirabbit Cy5, 1:200; Jackson ImmunoResearch, 711-175-152). Fluorescent images were visualized on an Olympus FluoView 1000 filter-based laser scanning confocal microscope. Immunofluorescence intensity per cell was assessed using NIH ImageJ software.

Chromatin immunoprecipitation. ChIP was performed essentially as described previously (Damez-Werno et al., 2012). Briefly, $1 \mathrm{~h}$ after the last injection, freshly dissected whole hippocampi were pooled from two mice for each ChIP and crosslinked with formaldehyde. The material was further sheared and immunoprecipitated using sheep anti-mouse magnetic beads (11201D, Invitrogen) conjugated to an antibody that specifically recognizes $\mathrm{H} 3 \mathrm{~K} 9 \mathrm{me} 2$ (ab1220, Abcam). Immunoprecipitated DNA was subjected to qRT-PCR analysis to examine enrichment along the Fos $B$ gene. Levels of chromatin modifications are compared with those for input DNA as described previously (Maze et al., 2010a). Primers used to assess the enrichment of histone posttranslational modifications along the FosB gene were as follows:

- 1200 Forward: ATGGGACTCAGGTTGTCAGG

- 1200 Reverse: AGCCAGGGCTACACAGAGAA

-900 Forward: AGGCTTCCAACACCATCAAG

-900 Reverse: TTCTGTGTGACTCGGTGAGC

-700 Forward: GCTCACCGAGTCACACAGAA

-700 Reverse: GCTGGTGAAAAAGAGCAAGG

-500 Forward: GAGTTGCACCTTCTCCAACC

-500 Reverse: GGCCCAGTGTTTGTTTGGTA

-250 Forward: ATGGCTAATTGCGTCACAGG

-250 Reverse: ACCTCCCAAACTCTCCСТTC

+1 Forward: GCTCCCGGTTTCATTCATAA

+1 Reverse: GCAAAAAGGAAACCCACAAA

+ 250 Forward: TTCTTTCTGTGGGCTTCTGG

+250 Reverse: TTTCGATGCAAGTTCCCTCT

+500 Forward: CTACTCCGGACTCGCATCTC

+500 Reverse: GAAGGAGTCCACCGAAGACA

+700 Forward: CGCCGAGTCTCAGTACCTGT

+700 Reverse: AACCAAAGTGCAAACCGAAC
+1100 Forward: TCCACCCAGCAAGAGTTAGG

+ 1100 Reverse: CTCGGCGTTCCAAAATAGAA

+1300 Forward: GCTTTAGCCAATCAGCGTTC

+1300 Reverse: CAGGTCCACACAAGGTCCTC

Western blotting. One hour after the last injection, brains were rapidly extracted on ice and then sliced into $1 \mathrm{~mm}$ sections. Whole dorsal hippocampus, ventral dentate gyrus, or ventral CA1 were removed with a 12 -gauge punch and immediately frozen on dry ice. Samples were processed for SDS-PAGE and transferred to PVDF membranes for Western blotting with chemiluminescence. Blots were probed for FosB (5G4; 1:500; Cell Signaling Technology, 2251S) and assayed for total protein using Swift Membrane Stain ( $G$ Biosciences). Protein was quantified using NIH ImageJ software.

$R N A$ isolation and $q R T-P C R$. One hour after the last injection, brains were rapidly extracted on ice and then sliced into $1 \mathrm{~mm}$ sections. Whole dorsal hippocampus, ventral dentate gyrus, or ventral CA1 were removed with a 12-gauge punch and immediately frozen on dry ice. RNA isolation, qRT-PCR and data analysis were performed as described previously (Covington et al., 2009). Briefly, RNA was isolated by TRIzol reagent (Invitrogen) according to the manufacturer's instructions and purified using the RNeasy micro kit (Qiagen, 74004). Quality was checked using a NanoDrop spectrophotometer (ThermoFisher Scientific) with purity of samples confirmed with a 260:280 ratio between 1.8 and 2.1. cDNA was made using the High Capacity cDNA Reverse Transcription Kit (Applied Biosystems, 4368814). qRT-PCR was conducted with the Bio-Rad CFX Connect RT PCR system with the following parameters: 10 min at $95^{\circ} \mathrm{C}$; 40 cycles of $95^{\circ} \mathrm{C}$ for $1 \mathrm{~min}, 60^{\circ} \mathrm{C}$ for $30 \mathrm{~s}, 72^{\circ} \mathrm{C}$ for $30 \mathrm{~s}$; graded heating to $95^{\circ} \mathrm{C}$ to generate dissociation curves for confirmation of single PCR products. Data were normalized to Gapdh levels measured in parallel. Data were analyzed by comparing $C(t)$ values of the treatment condition (saline vs cocaine exposure) with the $\Delta \Delta C(t)$ method (Robison et al., 2014).

FosB Forward: GTGAGAGATTTGCCAGGGTC

FosB Reverse: AGAGAGAAGCCGTCAGGTTG

$\triangle$ FosB Forward: AGGCAGAGCTGGAGTCGGAGAT

$\triangle$ FosB Reverse: GCCGAGGACTTGAACTTCACTCC

GAPDH Forward: AGGTCGGTGTGAACGGATTTG

GAPDH Reverse: TGTAGACCATGTAGTTGAGGTCA

Statistical analyses. All statistical analyses were performed using Prism software (GraphPad Software). Anxiety phenotypic behavior (OF activity and EPM), CFC freezing, protein and mRNA quantification, and locomotor activity were analyzed using unpaired Student's $t$ tests. NOR, ChIP, and cocaine CPP were analyzed using two-way (with or without repeated measures) ANOVAs followed by Holm-Sidak-corrected post hoc comparisons for simple effects. Alpha criterion of 0.05 was set for all analyses.

\section{Results \\ Induction of $\Delta$ FosB in hippocampal subregions and role in cocaine-related behaviors}

Induction of $\Delta$ FosB has been observed in the hippocampus in response to drugs of abuse such as morphine and cocaine (Perrotti et al., 2008). However, to date there has been neither quantification of this induction nor comparison between dorsal and ventral hippocampus. Therefore, we exposed mice to a novel environment paired with saline or cocaine $(20 \mathrm{mg} / \mathrm{kg})$ for 30 $\mathrm{min} / \mathrm{d}$ for $10 \mathrm{~d}$ and compared the expression of FosB isoforms in tissue punches of subregions of dorsal and ventral hippocampus. We were able to separate the ventral CA1 (vCA1) subregion from the rest of the ventral hippocampus [containing primarily CA3 and dentate gyrus (vDG)] because of the size of the ventral hippocampus, thus enriching for hippocampal cells that project from vCA1 to other regions of the brain critical for emotional learning and drug responses (Cooper et al., 2017). Unfortunately, this technique does not allow for the same separation of the dorsal hippocampus, because this region is much smaller. mRNA 

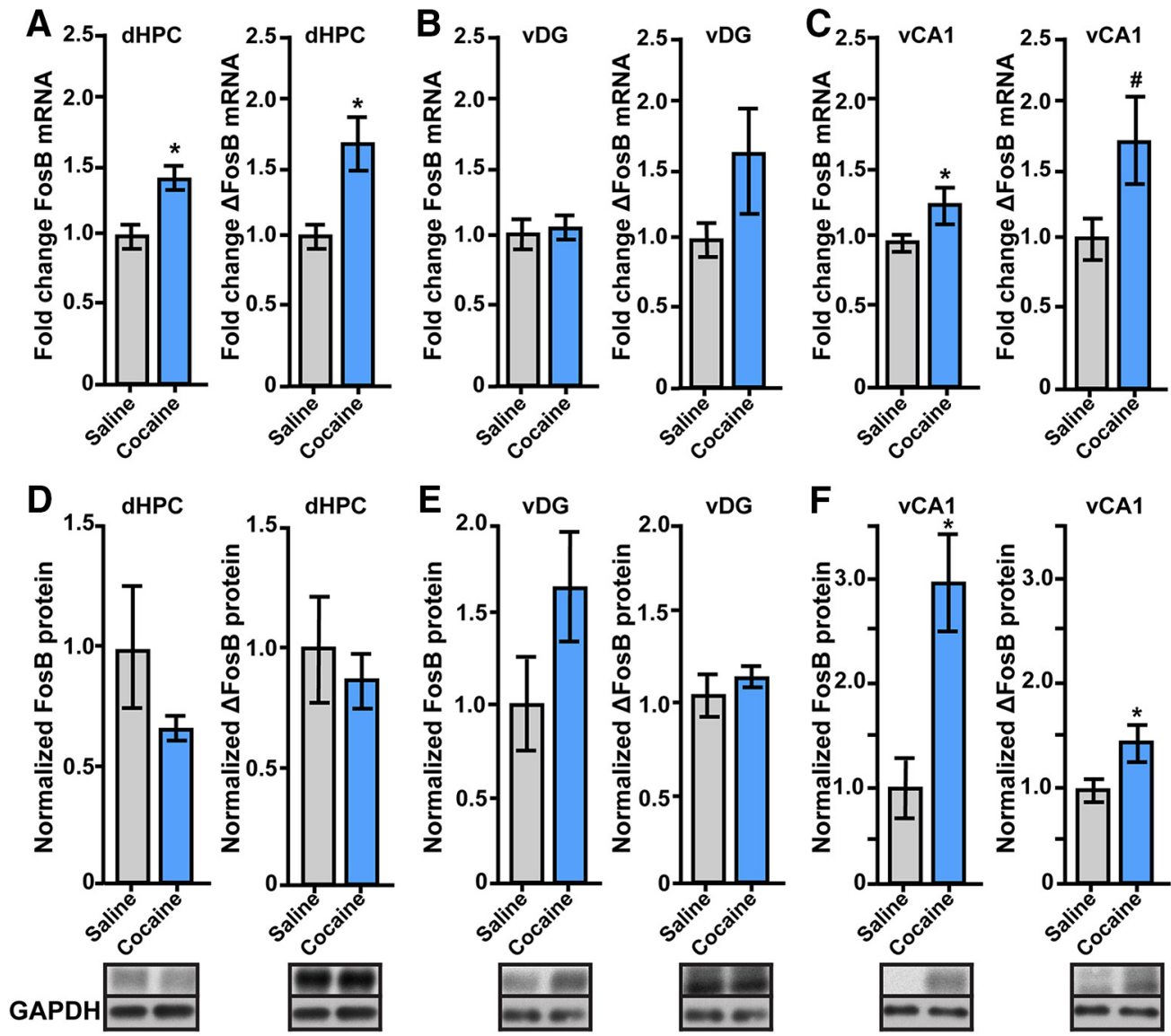

Figure 1. Cocaine effects on hippocampal expression of FosB isoforms. $A$, Mice were killed $1 \mathrm{~h}$ after the last exposure to saline or cocaine paired with a novel environment. qPCR reveals cocaine-dependent increases in the transcript levels for FosB and $\triangle$ FosB in whole dorsal hippocampus (dHPC). $\boldsymbol{B}$, Ventral hippocampus was microdissected to isolate the vDG, which displayed no changes in full-length FosB or $\triangle$ FosB mRNA. C, Specific microdissection of $v C A 1$ revealed a trend toward an increase in both FosB and $\triangle$ FosB mRNA. D, dHPC displayed no changes in either FosB or $\Delta$ FosB protein. $\boldsymbol{E}, \boldsymbol{F}, \mathrm{vDG}$ did not show any significant changes in FosB or $\triangle \mathrm{FosB}(\boldsymbol{E})$, and $\mathrm{V} C \mathrm{~A} 1$ showed significant induction of both FosB and $\Delta$ FosB $(\boldsymbol{F})$. At the bottom of each graph are representative images from Western blots showing FosB or $\Delta$ FosB, and GAPDH ( $n=8 /$ group; ${ }^{*} p<0.05$, \#p $\leq 0.06$ ).

was isolated to determine expression of each isoform in response to cocaine. There was significantly more FosB and $\Delta$ FosB mRNA in whole dorsal hippocampus after chronic cocaine exposure (Fig. $1 A$; FosB $t_{(14)}=3.307, p=0.005, \Delta$ FosB $t_{(13)}=2.608, p=$ $0.021)$. We also found strong trends toward increases in both isoforms in vCA1 (Fig. $1 C$; FosB vCA1 $t_{(14)}=2.112, p=0.053$; $\Delta$ FosB vCA1 $\left.t_{(14)}=2.026, p=0.062\right)$, though changes in vDG were weaker and more variable (Fig. $1 B$ ). We processed tissue from the same animals for Western blot to determine whether the relevant protein products were similarly regulated, and we found no significant changes in whole dorsal hippocampus FosB or $\Delta$ FosB protein levels between cocaine- and saline-treated mice (Fig. 1D). However, in vCA1, both FosB and $\Delta$ FosB were increased (Fig. $1 E$; FosB $t_{(12)}=3.658, p=0.003, \Delta$ FosB $t_{(12)}=$ 2.167, $p=0.05$ ).

Tissue dissection and Western blot do not allow resolution of cell type and can only crudely enrich for hippocampal subregion. To better assess changes in the neurons of subregions of the hippocampus, we completed the same cocaine exposure protocol and performed immunohistochemistry or immunofluorescence on coronal brain slices. As the antibody we use recognizes both full-length FosB and $\Delta$ FosB, we killed animals $24 \mathrm{~h}$ after the last drug exposure to enrich for the stable $\Delta$ FosB isoform (Perrotti et al., 2008; Ulery-Reynolds et al., 2009). We found an increase in the number of $\Delta$ FosB-positive neurons in the CA1 subregion of dorsal hippocampus after chronic cocaine exposure (Fig. 2A, C; $\left.t_{(7)}=3.001, p=0.019\right)$, but no significant changes in the dorsal DG or CA3 (Fig. $2 A, C$ ). In ventral hippocampus, there was also a significant increase in the number of $\triangle$ FosB-positive cells in CA1 with no change in DG and CA3 (Fig. $2 B, D ; t_{(12)}=2.37, p=$ 0.035). We also examined the intensity of $\Delta$ FosB fluorescence signal per neuron in the dorsal CA1 and found an increase in fluorescence intensity per cell (Fig. $2 E ; t_{(93)}=4.364, p<0.0001$ ). This suggests that drugs of abuse selectively induce $\Delta \mathrm{FosB}$ in specific hippocampal subregions, both in the number of neurons expressing $\Delta$ FosB and the amount of $\Delta$ FosB found in each neuron. We thus hypothesized that this induction may contribute to the formation of the strong associations between drugs and environment.

To determine whether the activity of hippocampal $\Delta$ FosB is necessary for cocaine-environment associations, we used AAVmediated expression of $\Delta \mathrm{JunD}$, a dominant-negative version of $\Delta$ FosB's obligate binding partner, JunD, to silence $\Delta$ FosB's transcriptional activity (Robison et al., 2013; Eagle et al., 2015). AAVs expressing GFP alone or GFP and $\triangle \mathrm{JunD}$ were targeted to the dorsal or ventral hippocampus (Fig. $3 A, B$ ). Our laboratory has previously examined $\Delta$ FosB in dorsal hippocampus-mediated general learning and memory and found that $\Delta \mathrm{JunD}$ produced impairments in dorsal hippocampal-dependent tasks (Eagle et al., 2015), but viral expression of $\Delta$ JunD in ventral hippocampus 
A

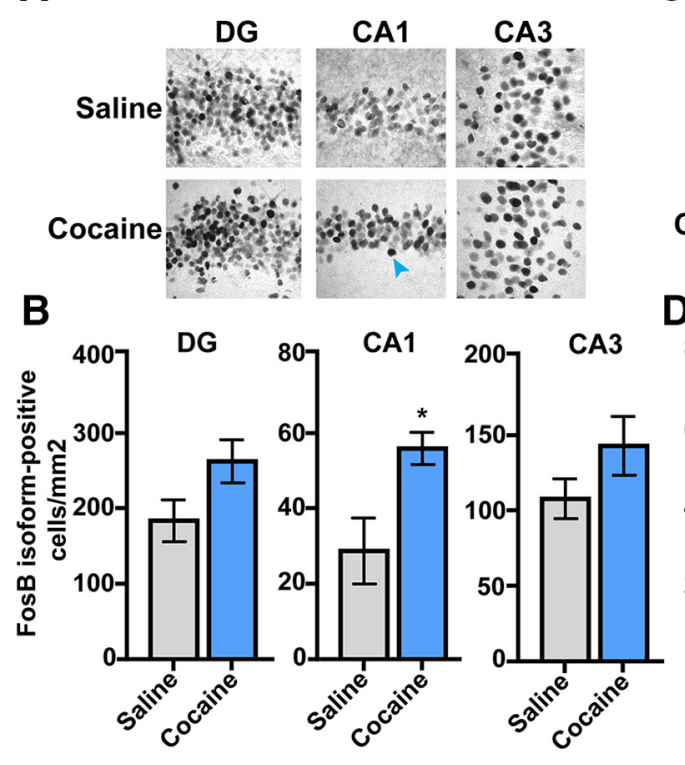

C

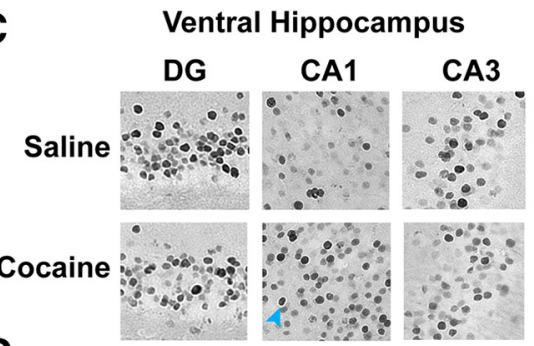

E
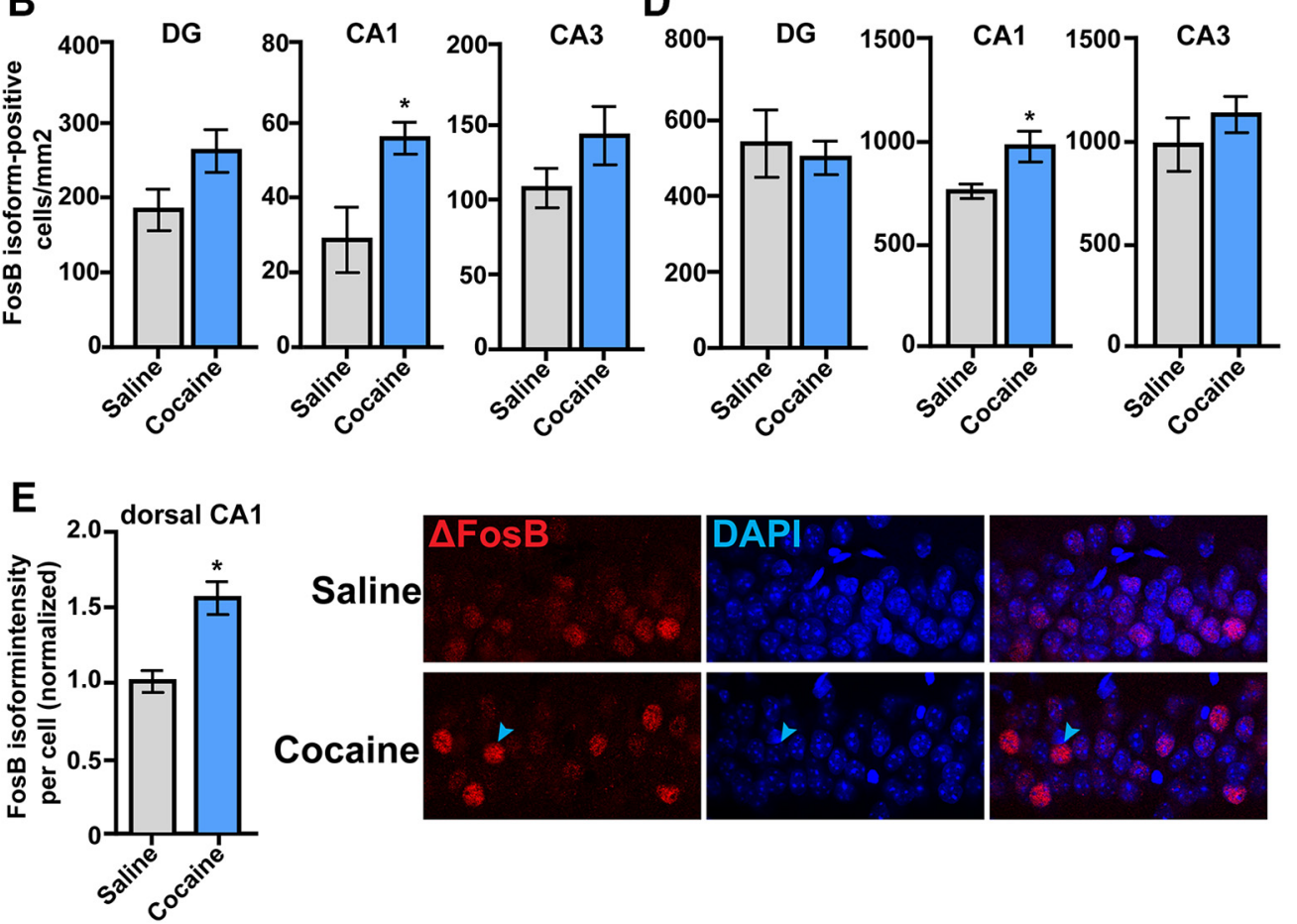

Figure 2. Cocaine effects on FosB-isoform neuronal expression in dorsal and ventral hippocampal subregions. $\boldsymbol{A}, \boldsymbol{B}$, Representative $40 \times$ images of coronal sections of dorsal $(\boldsymbol{A})$ and ventral $(\boldsymbol{B})$ hippocampus stained for FosB isoforms (and enriched for $\Delta$ Fos $B$ ) from mice given saline or cocaine in a novel environment. Arrowheads indicate examples of Fos $B$-isoform + cells. $C, D$, Cocaine increased FosB-isoform + cells specifically in the CA1 subregion of dorsal $(\boldsymbol{C})$ and ventral $(\boldsymbol{D})$ hippocampus $\left(n=5\right.$ mice; $\left.{ }^{*} p<0.05\right)$. $\boldsymbol{E}$, Quantified FosB-isoform intensity per cell in dorsal hippocampus CA1 neurons after chronic cocaine exposure $\left(n=25-60\right.$ cells; $\left.{ }^{*} p<0.05\right)$. Representative images show FosB-isoforms in red and DAPI in blue. Arrowhead indicates an example cell in which FosB isoforms are induced at high levels following chronic cocaine exposure.

has not been examined. To this end, we first examined the effects of viral expression of $\Delta$ JunD in ventral CA1 in hippocampaldependent learning and memory. We observed impairment in NOR (Fig. $3 C ; t_{(22)}=3.002, p=0.0131$ ), but no change in freezing behavior after CFC (Fig. $3 D ; t_{(25)}=0.7992, p=0.4317$ ). Freezing behavior was assessed in $1 \mathrm{~min}$ bins and no differences were found at any time point (data not shown). There was no significant difference in total distance moved in the NOR test (GFP: $1104.7 \pm 111.1 \mathrm{~cm}$; $\Delta$ JunD: $1117.8 \pm 64.9 \mathrm{~cm} ; p=0.92$ ). Because the ventral hippocampus projects to the amygdala (McDonald and Mott, 2017), we also tested anxiety-like behavior using OF and EPM. We observed no change in percentage time spent in center of the OF or percentage time in open arms of the EPM (Fig. $3 E$, F; OF: $t_{(22)}=1.271, p=0.217$; EPM: $t_{(17)}=0.7788$, $p=0.4468)$, indicating that general inhibition of ventral hippocampus $\Delta$ FosB does not affect anxiety, though this does not rule out a role for $\Delta \mathrm{FosB}$ in the specific projection neurons connecting these regions. We next examined the effect of $\Delta$ JunD in dorsal or ventral hippocampus on cocaine CPP and saw that expression in either region impaired CPP, because $\triangle \mathrm{JunD}$ expressing mice did not display a preference for the cocainepaired chamber, whereas GFP controls did (Fig. 3G,H; dorsal:
$F_{(1,58)}=5.634, p<0.0001$; ventral: $\left.F_{(1,40)}=9.9095, p<0.01\right)$. These data suggest that $\Delta$ FosB function in both dorsal and ventral hippocampus is critical for mediating conditioned place preference.

\section{Epigenetic modifications at the FosB gene in response to} chronic cocaine exposure

Induction of $\triangle \mathrm{FosB}$ in the NAc after cocaine exposure is mediated in part by a decrease in $\mathrm{H} 3 \mathrm{~K} 9 \mathrm{me} 2$ at the Fos $B$ gene (DamezWerno et al., 2012). Therefore, we assessed whether cocainemediated hippocampal $\Delta$ FosB induction was also facilitated by this modification. We conducted ChIP from whole hippocampus and found a cocaine-mediated decrease in $\mathrm{H} 3 \mathrm{~K} 9 \mathrm{me} 2$ at multiple points along the Fos $B$ promoter and gene body (Fig. $4 A$; RM ANOVA, $F_{(1,11)}=8.296, p=0.015$ for cocaine vs saline main effect). This suggests that the Fos $B$ gene is typically enriched with $\mathrm{H} 3 \mathrm{~K} 9 \mathrm{me} 2$, and that this mark is reduced after cocaine exposure to induce transcription (Fig. $4 B$, top).

To determine whether changes in $\mathrm{H} 3 \mathrm{~K} 9 \mathrm{me} 2$ are necessary for cocaine-mediated hippocampal $\Delta$ FosB induction and the subsequent hippocampal-dependent behavioral outputs, we used a viral vector that catalyzes $\mathrm{H} 3 \mathrm{~K} 9$ me 2 specifically at the FosB pro- 
moter (Heller et al., 2014). This HSV expresses a zinc finger protein (ZFP) designed to bind solely at the FosB promoter fused to the catalytic domain of the histone dimethyltransferase, G9a (Fig. 4B, bottom), and decreases FosB gene expression in NAc (Heller et al., 2014; Hamilton et al., 2018). To validate this effect in hippocampus, we measured $\Delta$ FosB immunofluorescence after either HSV-GFP or HSV-FosB-ZFP-G9a viral infection into the dorsal hippocampus and saw that HSVFosB-ZFP-G9a prevented the cocainemediated increase in the intensity of $\Delta$ FosB signal (Fig. $4 C, D ; F_{(5,192)}=14.29$, $p<0.0001)$. This suggests that enrichment of $\mathrm{H} 3 \mathrm{~K} 9 \mathrm{me} 2$ at the FosB promoter inhibits the cocaine-mediated induction of $\Delta$ FosB.

General silencing of $\Delta$ FosB transcriptional activity in dorsal hippocampus using the dominant-negative $\Delta \mathrm{JunD}$ leads to an impairment of hippocampal-dependent learning and memory tasks (Eagle et al., 2016). We injected HSV-FosB-ZFPG9a into dorsal hippocampus and saw similar impairments in learning and memory to those observed with $\Delta$ JunD. Mice exhibited an impairment in novel object recognition (Fig. $5 A ; t_{(16)}=2.817$, $p=0.012$ ) with no changes in CFC or locomotor activity (Fig. $5 B, C$; CFC: $t_{(11)}$ $=0.1657, p=0.8714$; activity: $t_{(14)}=$ $0.6456, p=0.5290)$. There was no significant difference in total distance moved in the NOR (GFP: $1093.6 \pm 106.1 \mathrm{~cm}$; G9a: $997.1 \pm 55.2 \mathrm{~cm} ; p=0.43)$. We also show that HSV-FosB-ZFP-G9a injection into dorsal hippocampus had no effect on short-term memory, because novel object recognition performed only $4 \mathrm{~h}$ after familiarization with objects was unaffected (Fig. 5D). When the FosB-ZFP-G9a virus was targeted to the ventral hippocampus, we also saw impairments in novel object recognition (Fig. $5 E$; $t_{(36)}=2.386, p=$ 0.022 ) with no changes in CFC or locomotor activity (Fig. $5 F, G$; CFC: $t_{(7)}=$ $0.1109, p=0.9148$; activity: $t_{(9)}=0.2173$, $p=0.8328$ ). Freezing behavior was assessed in $1 \mathrm{~min}$ bins, and no significant differences were found at any time points (data not shown). There was no significant difference in total distance moved in the NOR (GFP: $1194.8 \pm 76.3 \mathrm{~cm}$; G9a: $1037.1 \pm 118.8 \mathrm{~cm} ; p=0.28)$. These data suggest that increasing $\mathrm{H} 3 \mathrm{~K} 9 \mathrm{me} 2$ at the FosB promoter can prevent FosB/ $\Delta$ FosB-driven hippocampus-dependent behaviors.

Because cocaine mediates a decrease of $\mathrm{H} 3 \mathrm{~K} 9 \mathrm{me} 2$ at the FosB gene in hippocampus, we investigated whether H3K9me2 deposition at the $F o s B$ gene is sufficient to impair hippocampusdependent cocaine-environment associations. Mice were injected with HSV-GFP or HSV-FosB-ZFP-G9a into dorsal or ventral hip-
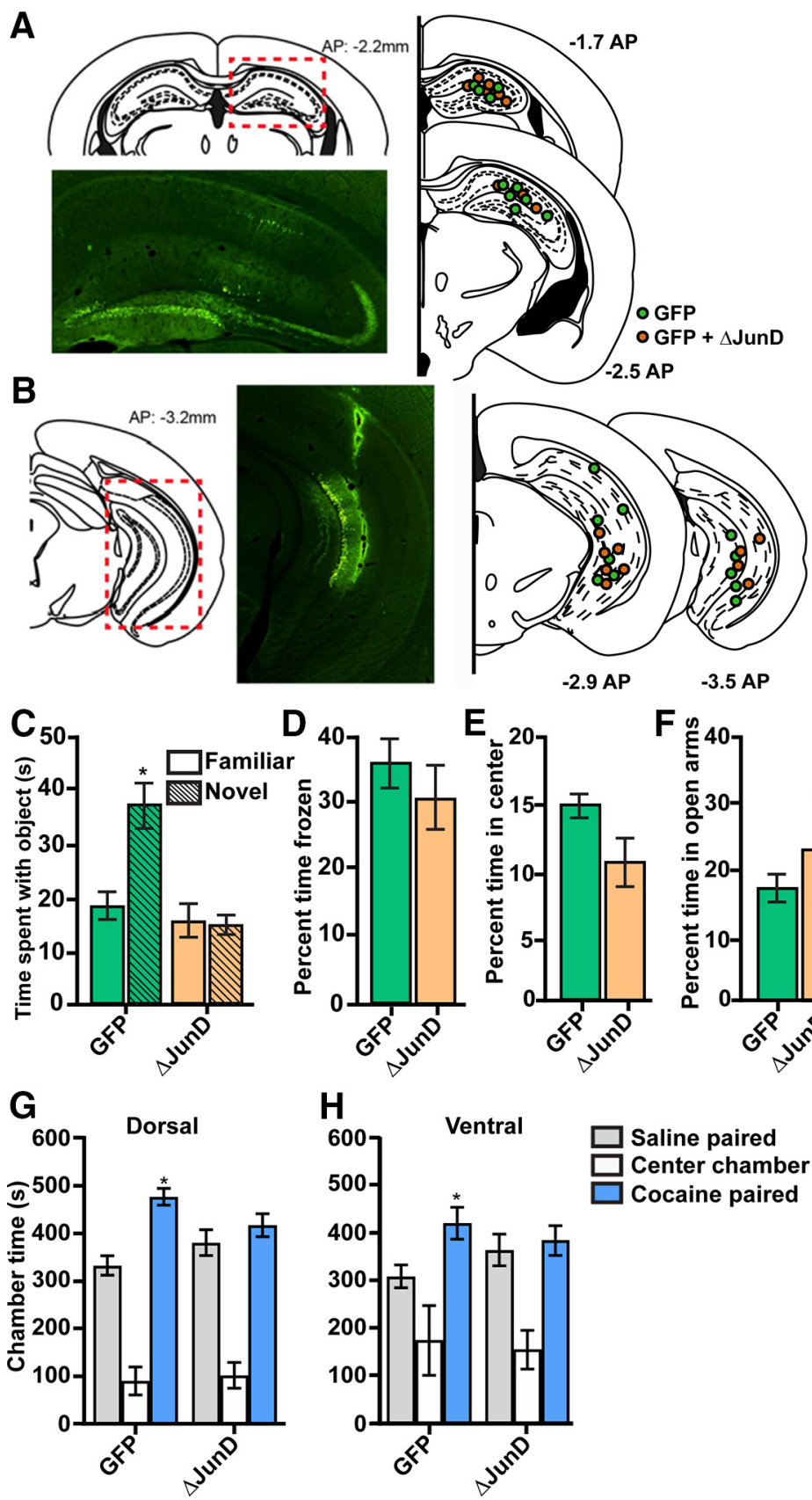

Figure 3. Transcriptional silencing of hippocampal $\Delta$ FosB impairs cocaine conditioned place preference. $A$, Example of dorsal hippocampal targeting of viral-mediated GFP expression (left) and injection sites of a representative cohort of dorsal hippocampal surgeries with AAV-GFP or AAV- $\Delta$ JunD (right). B Example of ventral hippocampal targeting (left) and injection sites (right). $\boldsymbol{C}$, Mice received ventral hippocampal infusions of AAV-GFP or AAV- $\Delta$ JunD. GFP mice spent significantly more time with the novel object than the familiar object, whereas the $\triangle$ JunD mice showed impaired novel object recognition. There was no difference between ventral hippocampus AAV-GFP or AAV- $\Delta$ JunD in CFC freezing behavior $(\boldsymbol{D})$, center zone time in $0 \mathrm{~F}(\boldsymbol{E})$, or open arm time in EPM $\left(\boldsymbol{F} ; n=6-7 ;{ }^{*} p<0.05\right)$. Mice were injected in dorsal $(\boldsymbol{G})$ or ventral $(\boldsymbol{H})$ hippocampus with HSV-GFP or HSV- $\Delta$ JunD and subjected to cocaine CPP (5 mg/kg, i.p.). Control mice formed a significant preference for the cocaine-paired chamber, which was blocked by HSV- $\Delta$ JunD in either hippocampal region $\left(n=8,{ }^{*} p<0.05\right)$.

pocampus, allowed to recover for $24 \mathrm{~h}$, and then exposed to cocaine and saline conditioning for $2 \mathrm{~d}$. Mice that received FosBZFP-G9a in either the dorsal or ventral hippocampus displayed impaired cocaine CPP (Fig. $6 \mathrm{~A}, B$; dorsal: $F_{(1,42)}=5.436, p=$ 0.025 ; ventral: $\left.F_{(1,36)}=4.048, p=0.0496\right)$. Thus, cocainemediated epigenetic changes at the Fos $B$ promoter in both dorsal and ventral hippocampus appear necessary for mediating cocaine conditioned place preference. 

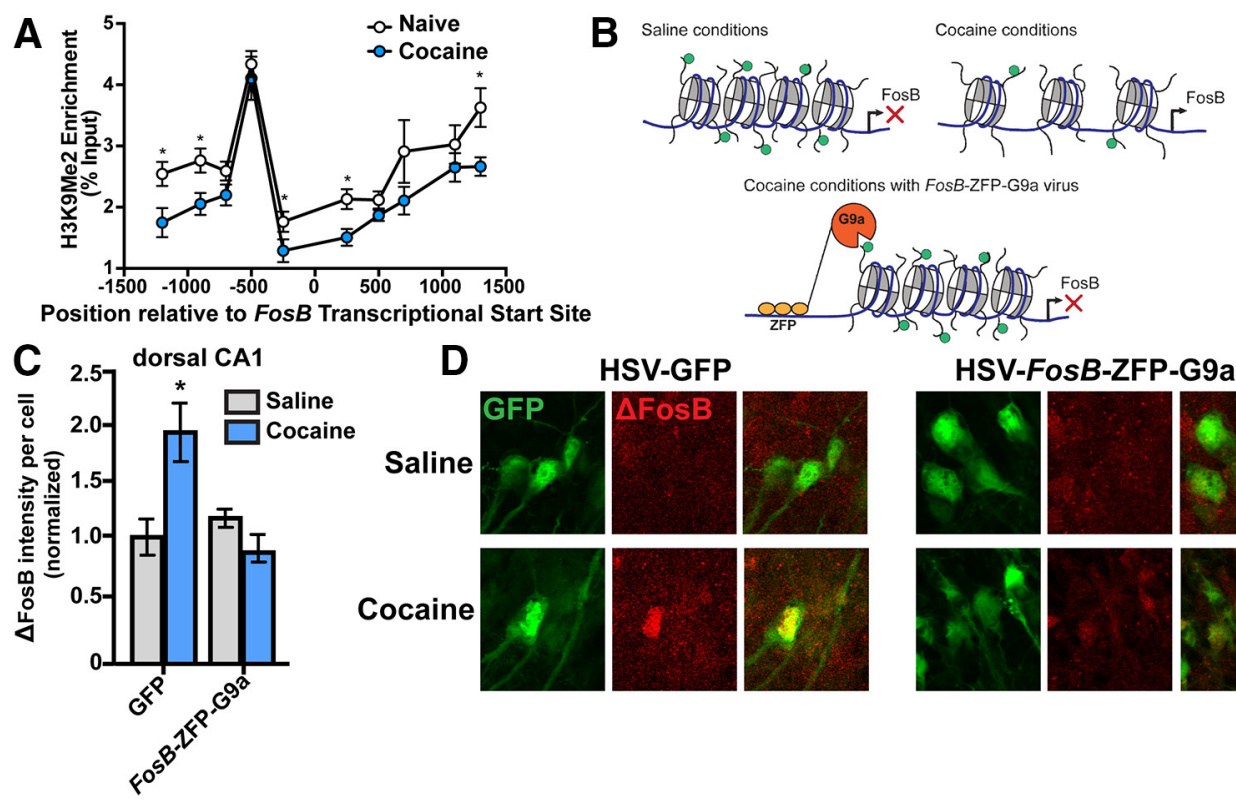

D HSV-GFP
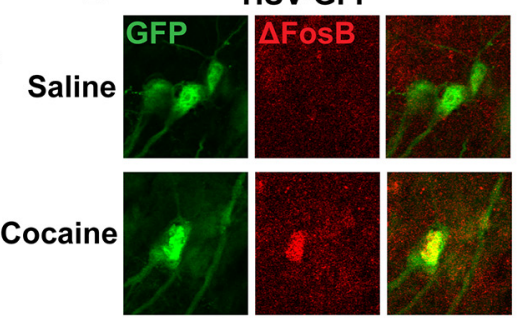

HSV-FosB-ZFP-G9a


Figure 4. Reduction of H3K9me2 at the Fos B promoter is required for cocaine induction of $\Delta \mathrm{FosB}$ in ventral hippocampus. A, Mice were injected with cocaine (20 mg/kg, i.p.) or saline and placed in a novel environment for $30 \mathrm{~min} / \mathrm{d}$ for $10 \mathrm{~d}$. Chromatin immunoprecipitation for H3K9me2 was conducted on microdissected hippocampus, which was taken $1 \mathrm{~h}$ after the last injection. Significant decreases in H3K9me2 enrichment were found at multiple sites along the Fos $B$ gene $\left(n=8 ;{ }^{*} p<0.05\right)$. B, Diagram of histone posttranslational modifications at the Fos $B$ gene before and after cocaine exposure, and depicting locus-specific H3K9me2 deposition at the FosB promoter. Graphs $(\boldsymbol{C})$ and representative images $(\boldsymbol{D})$ of ventral hippocampus CA1 neurons in saline and cocainetreated mice. $\Delta$ FosB (red) was significantly increased by cocaine in neurons of mice injected with HSV-GFP, but not HSV-FosB-ZFP-G9a (green; $n=16-30 ;{ }^{*} p<0.05$ ).
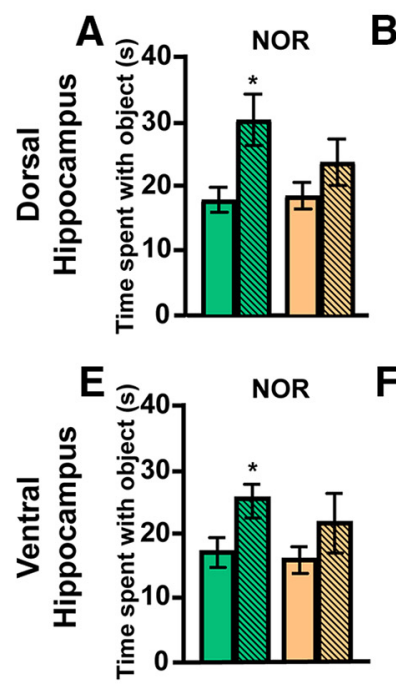

Figure 5. Epigenetic remodeling by FosB-ZFP-G9a in dorsal and ventral hippocampus impairs general learning and memory. $\boldsymbol{A}$, Dorsal hippocampus HSV-GFP mice spent significantly more time with the novel object than the familiar object, whereas Fos $B$ ZFP-G9a mice spent a similar amount of time with both objects $\left(n=8-18 ;{ }^{*} p<0.05\right)$. B, After CFC, FosB-ZFP-G9a mice spent the same amount of time freezing as GFP controls. C, There was no difference locomotor activity between groups. $\boldsymbol{D}$, Short-term memory, as measured by time with the novel object only $4 \mathrm{~h}$ after familiarization, was not affected FosB-ZFP-G9a expression in dorsal hippocampus. $E$, Ventral hippocampus HSV-GFP mice spent significantly more time with the novel object than the familiar object, whereas FosB-ZFP-G9a mice spent a similar amount of time with both objects. There were no differences in CFC $(\boldsymbol{E})$ or locomotor activity $\left(\boldsymbol{F} ; n=8-18 ;{ }^{*} p<0.05\right)$. $\mathbf{G}$, There was no difference locomotor activity between groups.

\section{Discussion}

One of the critical obstacles in treatment of addiction is the strength and persistence of drug-associated memories, implicating a role for dysregulated hippocampal activity in addiction. Here, we present the first quantitative evidence for cocainemediated induction of FosB isoforms within specific subregions of the hippocampus and altered histone posttranslational modi-
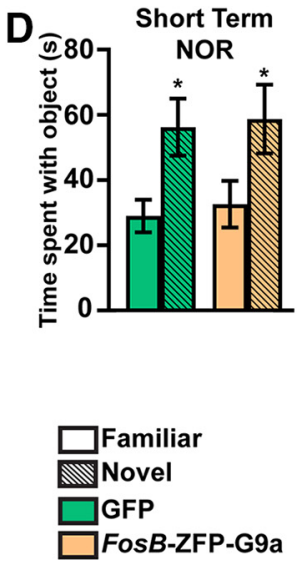

fications associated with this induction. Both $\triangle$ FosB induction and cocaine CPP were blocked by viral overexpression of the FosB-ZFP-G9a fusion protein in hippocampus. This indicates that enrichment of $\mathrm{H} 3 \mathrm{~K} 9 \mathrm{me} 2$ at the FosB promoter is sufficient to suppress $\Delta$ FosB expression and subsequent cocaineenvironment associations.

The hippocampus is essential in the formation of associations concerning cues and events in a drug context (Fuchs et al., 2005). Memories of cocaine-associated stimuli are extremely persistent and resistant to extinction, thus cocaine addiction can be considered a learning and memory disease (Kutlu and Gould, 2016), and indeed, drug-associated stimuli can induce craving and relapse even during abstinence (Gawin and Kleber, 1986). Therefore, molecular and functional changes in the hippocampus that occur in response to cocaine exposure may give us critical insight into the establishment of these drug-associated memories.

Induction of full-length FosB and $\Delta$ FosB in the dorsal hippocampus has been previously reported with both experimenter- and self-administered cocaine, as well as stress and antidepressants (Perrotti et al., 2008; Vialou et al., 2015). Here, we used $20 \mathrm{mg} / \mathrm{kg}$ cocaine intraperitoneal injection to assess induction of FosB and $\Delta$ FosB in dorsal and ventral hippocampus subregions, because this dose is well known to cause robust induction throughout the brain (Perrotti et al., 2008; Robison et al., 2013). It is important to note that the lower dose of cocaine $(5 \mathrm{mg} / \mathrm{kg}$ ) used in CPP was chosen to allow 
us to observe either increased or decreased cocaine preference, because a ceiling effect is reached when mice are given higher doses of cocaine (Kelz et al., 1999). Induction in both dorsal and ventral hippocampus CA1 by chronic intraperitoneal cocaine is unsurprising as CA1 neurons undergo a variety of changes in response to cocaine (Miguéns et al., 2015; Keralapurath et al., 2017), and also play key roles in circuitry underlying associations of salient stimuli with environmental cues. The dorsal CA1 is especially important for contextual encoding and contextualdependent retrieval compared with the other subregions (Ji and Maren, 2008; Zhu et al., 2014). Ventral CA1 projects to reward circuitry, including NAc and parts of the cortex, and these circuits regulate many addiction-related behaviors includ-

ing cue- and context-induced drug seeking, from heroin (Wang et al., 2018) to cocaine (Pascoli et al., 2014). Thus, the CA1 may be uniquely positioned to modulate the role of memory in drug addiction (Zornoza et al., 2005).

Using immunohistochemistry, previous studies showed qualitative increases in $F o s B$ gene products in dorsal hippocampus after cocaine (Perrotti et al., 2008). Our initial Western blots did not reveal $\Delta$ FosB induction in dorsal hippocampus after cocaine exposure. However, transcript levels of FosB and $\Delta$ FosB were increased in whole dorsal hippocampus, suggesting that chronic cocaine exposure mediates active transcription of the Fos $B$ gene in this region, but that additional regulation at the translational or proteolytic level may prevent overall differences in protein. It is also possible that current FosB antibodies lack the sensitivity and/or specificity to uncover subtle changes in $\Delta$ FosB levels, and production of better antibodies for FosB isoforms is a current goal for the field. Moreover, the FosB gene is expressed in many subtypes of neurons as well as in microglia (Nomaru et al., 2014), so it is possible that at the time of kill ( $1 \mathrm{~h}$ after the last injection), protein levels may be increased in one cell type, whereas mRNA is increased in a different cell type. Furthermore, the use of tissue punches and qRT-PCR or Western blot do not allow us to distinguish between cell type or subregion, and thus the use of immunohistochemistry was critical to determine whether the changes in protein we observed were occurring in neurons relevant to the behaviors we are studying (i.e., CA1 pyramidal neurons). Increases in both FosB and $\Delta$ FosB protein became apparent when ventral CA1 was specifically targeted for dissection, and further examination using immunohistochemistry revealed increases in $\Delta$ FosB-positive cells in the dorsal and ventral CA1, presumably in pyramidal neurons based on the location of the staining. The dorsal CA1 subregion makes up a relatively small portion of the whole dorsal hippocampus, which may explain the lack of induction of FosB $/ \Delta$ FosB seen in the Western blot analysis. Increases in the number of $\Delta \mathrm{FosB}+$ cells in the dorsal CA1 has also been observed after mice go through spatial learning via the Morris water maze (Eagle et al., 2015), suggesting that both general and drug-related learning may be mediated by dorsal CA1 $\Delta$ FosB. It is important to note that the immunohistochemical staining experiments were performed on animals killed $24 \mathrm{~h}$ after their last cocaine injection, whereas ChIP, qPCR, and Western blot experiments were performed on animals killed $1 \mathrm{~h}$ after the last injection. The $24 \mathrm{~h}$ time point was chosen for staining as it allows for relative enrichment for $\Delta$ FosB over other FosB isoforms (Perrotti et al., 2008; Ulery-Reynolds et al., 2009; Cates et al., 2014; Vialou et al., 2015). It is possible that differential transcriptional and epigenetic machinery could be engaged at these two time points, but the induction of $\Delta$ FosB at both time points is relevant, especially as the hippocampus plays a significant role in cocaine withdrawal-related behaviors (Ary and Szumlinski, 2007).

Induction of $\Delta$ FosB in ventral CA1 may be indicative of increased activity of those neurons that project to reward circuitry. Exposure to repeated cocaine and subsequent stimulation of the ventral hippocampus enhances dopamine release in NAc, suggesting that ventral CA1 neurons may regulate the effects of cocaine exposure on reward processing (Barr et al., 2014). Additionally, ventral hippocampal stimulation induces cocaine seeking in a self-administration paradigm even after extinction (Vorel et al., 2001), and synaptic plasticity at ventral CA1-NAc synapses is critical for cocaine seeking (Pascoli et al., 2014). Because we know that $\Delta$ FosB regulates glutamatergic synapse function in NAc MSNs (Grueter et al., 2013), it is possible that cocaine induction of $\Delta$ FosB ventral CA1 neurons projecting to NAc may alter synaptic function to regulate drug-related learning.

Although we have known for decades that chronic exposure to cocaine induces $\Delta$ FosB in the brain, the mechanisms of that induction are only now becoming clearer. $\mathrm{H} 3 \mathrm{~K} 9 \mathrm{me} 2$ is decreased at the FosB gene in the NAc of rats after withdrawal from chronic cocaine, regardless of exposure to a challenge dose of cocaine (Damez-Werno et al., 2012). H3K4me3 and H3K27me3, permissive and repressive histone marks, respectively, were also examined in the same rats, but no changes were found, indicating that FosB induction in NAc may be occurring specifically because of the decrease in $\mathrm{H} 3 \mathrm{~K} 9 \mathrm{me} 2$ in the promoter region. Critically, $\mathrm{H} 3 \mathrm{~K} 9 \mathrm{me} 2$ at the FosB gene is indeed sufficient to impair cocainemediated induction of FosB isoforms in NAc (Heller et al., 2014), and our data support the same conclusion in hippocampus. This histone tail modification is written by the histone methyltransferase G9a, which is also regulated in NAc by cocaine (Maze et al., 2010 b), and which plays an important role in hippocampal gene activation and silencing during memory consolidation (GuptaAgarwal et al., 2012). H3K9me2 is typically recognized by the silencing factor heterochromatin protein 1 (HP1), which then modifies the structure of local chromatin to regulate gene expression (Nishibuchi and Nakayama, 2014), but the role of HP1 in hippocampal function has not been well characterized. Future studies will investigate whether these upstream and downstream mediators of $\mathrm{H} 3 \mathrm{~K} 9 \mathrm{me} 2$ are regulated in hippocampus in response to 
cocaine, and whether interference with their function affects FosB gene induction or cocaine-environment associations.

Previous work from our laboratory silenced dorsal hippocampal FosB $/ \Delta$ FosB activity by overexpression of $\Delta \mathrm{JunD}$, and this caused impairment in a variety of learning tasks (Eagle et al., 2015). Interestingly, whereas $\Delta$ JunD impaired CFC, causing the mice to freeze less when exposed to the fear context (Eagle et al., 2015), the FosB-ZFP-G9a virus did not result in impaired fear learning (though both impaired recognition memory). This may be because of subtle differences in the two methodologies. For example, whereas $\Delta$ JunD inhibits all $\Delta$ FosB in the cell, overexpression of ZFP-G9a affects the FosB gene, thus preventing new $\Delta$ FosB from being produced, leaving existing $\Delta$ FosB available; a critical point, because $\Delta$ FosB is quite stable (Ulery-Reynolds et al., 2009). This suggests that existing $\Delta$ FosB may be sufficient for fear memory formation, whereas new $\Delta$ FosB production may be necessary for recognition memory. Additionally, overexpression of $\Delta$ JunD in the ventral hippocampus showed similar behavioral impairments to those observed with expression of ZFP-G9a-FosB in that region, with impairments in novel object recognition, and no changes in freezing behavior after CFC. The lack of change in fear memory is a surprising result, because the ventral hippocampus has projections to the amygdala that influence fear memory (Xu et al., 2016). However, the effects of $\Delta$ FosB may differ by projection, or the transduction of many cell types throughout the ventral hippocampus by our viral vectors may be offsetting celltype-specific effects.

Finally, we observed that preventing $\Delta \mathrm{FosB}$ induction or function in either the dorsal or ventral hippocampus impaired cocaine CPP. In contrast, lesion experiments suggest that dorsal, but not ventral, hippocampus is necessary for cocaine CPP (Meyers et al., 2003). However, these studies remove entire brain regions and associated circuits, whereas our manipulations of $\Delta$ FosB, and presumably downstream gene target expression, are much subtler and may engage circuits or mechanisms that affect CPP expression. Some of the known gene targets of $\Delta \mathrm{FosB}$, including glutamate receptors and calcium/calmodulin-dependent protein kinase II (Vialou et al., 2010; Robison et al., 2013), are directly tied to hippocampal neuronal function and to addiction (Robison, 2014; Spencer et al., 2016). Future studies will interrogate the expression of $\Delta \mathrm{FosB}$ in specific projection neurons, as ventral CA1 projections to NAc may provide a unique substrate for the integration of memory and drug-seeking behavior (Vorel et al., 2001; Pascoli et al., 2014).

The studies presented here provide strong evidence for the importance of histone modifications at the FosB gene in hippocampal induction of $\Delta$ FosB by cocaine and the critical role of this epigenetic regulation in subsequent drug responses. Overall, these results support a model in which exposure to cocaine alters the epigenetic landscape of the hippocampal FosB gene, inducing expression and driving persistent memories and behaviors that may contribute to cocaine addiction.

\section{References}

Adinoff B, Gu H, Merrick C, McHugh M, Jeon-Slaughter H, Lu H, Yang Y, Stein EA (2015) Basal hippocampal activity and its functional connectivity predicts cocaine relapse. Biol Psychiatry 78:496-504.

Ary AW, Szumlinski KK (2007) Regional differences in the effects of withdrawal from repeated cocaine upon homer and glutamate receptor expression: a two-species comparison. Brain Res 1184:295-305.

Barr JL, Forster GL, Unterwald EM (2014) Repeated cocaine enhances ventral hippocampal-stimulated dopamine efflux in the nucleus accumbens and alters ventral hippocampal NMDA receptor subunit expression. J Neurochem 130:583-590.
Benevento M, van de Molengraft M, van Westen R, van Bokhoven H, Kasri NN (2015) The role of chromatin repressive marks in cognition and disease: a focus on the repressive complex GLP/G9a. Neurobiol Learn Mem 124:88-96.

Cates HM, Thibault M, Pfau M, Heller E, Eagle A, Gajewski P, Bagot R, Colangelo C, Abbott T, Rudenko G, Neve R, Nestler EJ, Robison AJ (2014) Threonine 149 phosphorylation enhances $\delta$ FosB transcriptional activity to control psychomotor responses to cocaine. J Neurosci 34 : 11461-11469.

Chen J, Zhang Y, Kelz MB, Steffen C, Ang ES, Zeng L, Nestler EJ (2000) Induction of cyclin-dependent kinase 5 in the hippocampus by chronic electroconvulsive seizures: role of $\delta$ FosB. J Neurosci 20:8965-8971.

Cooper S, Robison AJ, Mazei-Robison MS (2017) Reward circuitry in addiction. Neurotherapeutics 14:687-697.

Covington HE 3rd, Maze I, LaPlant QC, Vialou VF, Ohnishi YN, Berton O, Fass DM, Renthal W, Rush AJ 3rd, Wu EY, Ghose S, Krishnan V, Russo SJ, Tamminga C, Haggarty SJ, Nestler EJ (2009) Antidepressant actions of histone deacetylase inhibitors. J Neurosci 29:11451-11460.

Damez-Werno D, LaPlant Q, Sun H, Scobie KN, Dietz DM, Walker IM, Koo JW, Vialou VF, Mouzon E, Russo SJ, Nestler EJ (2012) Drug experience epigenetically primes FosB gene inducibility in rat nucleus accumbens. J Neurosci 32:10267-10272.

Eagle AL, Gajewski PA, Yang M, Kechner ME, Al Masraf BS, Kennedy PJ, Wang H, Mazei-Robison MS, Robison AJ (2015) Experience-dependent induction of hippocampal $\delta$ FosB controls learning. J Neurosci 35:1377313783.

Eagle AL, Gajewski PA, Robison AJ (2016) Role of hippocampal activityinduced transcription in memory consolidation. Rev Neurosci 27:559573.

Fuchs RA, Evans KA, Ledford CC, Parker MP, Case JM, Mehta RH, See RE (2005) The role of the dorsomedial prefrontal cortex, basolateral amygdala, and dorsal hippocampus in contextual reinstatement of cocaine seeking in rats. Neuropsychopharmacology 30:296-309.

Gawin FH, Kleber HD (1986) Abstinence symptomatology and psychiatric diagnosis in cocaine abusers: clinical observations. Arch Gen Psychiatry 43:107-113.

Grueter BA, Robison AJ, Neve RL, Nestler EJ, Malenka RC (2013) FosB differentially modulates nucleus accumbens direct and indirect pathway function. Proc Natl Acad Sci U S A 110:1923-1928.

Gupta-Agarwal S, Franklin AV, Deramus T, Wheelock M, Davis RL, McMahon LL, Lubin FD (2012) G9a/GLP histone lysine dimethyltransferase complex activity in the hippocampus and the entorhinal cortex is required for gene activation and silencing during memory consolidation. J Neurosci 32:5440-5453.

Hamilton PJ, Burek DJ, Lombroso SI, Neve RL, Robison AJ, Nestler EJ, Heller EA (2018) Cell-type-specific epigenetic editing at the FosB gene controls susceptibility to social defeat stress. Neuropsychopharmacology 43:272284.

Heller EA, Cates HM, Peña CJ, Sun H, Shao N, Feng J, Golden SA, Herman JP, Walsh JJ, Mazei-Robison M, Ferguson D, Knight S, Gerber MA, Nievera C, Han MH, Russo SJ, Tamminga CS, Neve RL, Shen L, Zhang HS, et al. (2014) Locus-specific epigenetic remodeling controls addiction- and depression-related behaviors. Nat Neurosci 17:1720-1727.

Iñiguez SD, Riggs LM, Nieto SJ, Wright KN, Zamora NN, Cruz B, Zavala AR, Robison AJ, Mazei-Robison MS (2015) Fluoxetine exposure during adolescence increases preference for cocaine in adulthood. Sci Rep 5:15009.

Ji J, Maren S (2008) Differential roles for hippocampal areas CA1 and CA3 in the contextual encoding and retrieval of extinguished fear. Learn Mem 15:244-251.

Kalda A, Zharkovsky A (2015) Epigenetic mechanisms of psychostimulantinduced addiction. Int Rev Neurobiol 120:85-105.

Kelz MB, Chen J, Carlezon WA Jr, Whisler K, Gilden L, Beckmann AM, Steffen C, Zhang YJ, Marotti L, Self DW, Tkatch T, Baranauskas G, Surmeier DJ, Neve RL, Duman RS, Picciotto MR, Nestler EJ (1999) Expression of the transcription factor $\delta$ FosB in the brain controls sensitivity to cocaine. Nature 401:272-276.

Kennedy AJ, Rahn EJ, Paulukaitis BS, Savell KE, Kordasiewicz HB, Wang J, Lewis JW, Posey J, Strange SK, Guzman-Karlsson MC, Phillips SE, Decker K, Motley ST, Swayze EE, Ecker DJ, Michael TP, Day JJ, Sweatt JD (2016) Tcf4 regulates synaptic plasticity, DNA methylation, and memory function. Cell Rep 16:2666-2685.

Keralapurath MM, Clark JK, Hammond S, Wagner JJ (2014) Cocaine- or 
stress-induced metaplasticity of LTP in the dorsal and ventral hippocampus. Hippocampus 24:577-590.

Keralapurath MM, Briggs SB, Wagner JJ (2017) Cocaine self-administration induces changes in synaptic transmission and plasticity in ventral hippocampus. Addict Biol 22:446-456.

Krasnova IN, Li SM, Wood WH, McCoy MT, Prabhu VV, Becker KG, Katz JL, Cadet JL (2008) Transcriptional responses to reinforcing effects of cocaine in the rat hippocampus and cortex. Genes Brain Behav 7:193-202.

Kutlu MG, Gould TJ (2016) Effects of drugs of abuse on hippocampal plasticity and hippocampus-dependent learning and memory: contributions to development and maintenance of addiction. Learn Mem 23:515-533.

Maze I, Schaefer A, dietz D, Covington HE 3rd, sampath SC, Tarakhovsky A, Greengard P, Nestler EJ (2010a) G9a regulates cocaine-induced behavioral and transcriptional plasticity in a cell-type specific manner. Soc Neurosci Abstr 36:574.7.

Maze I, Covington HE 3rd, Dietz DM, LaPlant Q, Renthal W, Russo SJ, Mechanic M, Mouzon E, Neve RL, Haggarty SJ, Ren Y, Sampath SC, Hurd YL, Greengard P, Tarakhovsky A, Schaefer A, Nestler EJ (2010b) Essential role of the histone methyltransferase G9a in cocaine-induced plasticity. Science 327:213-216.

McDonald AJ, Mott DD (2017) Functional neuroanatomy of amygdalohippocampal interconnections and their role in learning and memory. J Neurosci Res 95:797-820.

McEwen BS (2016) In pursuit of resilience: stress, epigenetics, and brain plasticity. Ann N Y Acad Sci 1373:56-64.

Meyers RA, Zavala AR, Neisewander JL (2003) Dorsal, but not ventral, hippocampal lesions disrupt cocaine place conditioning. Neuroreport 14: 2127-2131.

Miguéns M, Kastanauskaite A, Coria SM, Selvas A, Ballesteros-Yañez I, DeFelipe J, Ambrosio E (2015) The effects of cocaine self-administration on dendritic spine density in the rat hippocampus are dependent on genetic background. Cereb Cortex 25:56-65.

Nishibuchi G, Nakayama J (2014) Biochemical and structural properties of heterochromatin protein 1: understanding its role in chromatin assembly. J Biochem 156:11-20.

Nomaru H, Sakumi K, Katogi A, Ohnishi YN, Kajitani K, Tsuchimoto D, Nestler EJ, Nakabeppu Y (2014) FosB gene products contribute to excitotoxic microglial activation by regulating the expression of complement C5a receptors in microglia. Glia 62:1284-1298.

Núñez C, Martín F, Földes A, Luisa Laorden M, Kovács KJ, Victoria Milanés $M$ (2010) Induction of FosB/ $\delta$ FosB in the brain stress system-related structures during morphine dependence and withdrawal. J Neurochem 114:475-487.

Pascoli V, Terrier J, Espallergues J, Valjent E, O'Connor EC, Lüscher C (2014) Contrasting forms of cocaine-evoked plasticity control components of relapse. Nature 509:459-464.

Perez MF, Gabach LA, Almiron RS, Carlini VP, De Barioglio SR, Ramirez OA (2010) Different chronic cocaine administration protocols induce changes on dentate gyrus plasticity and hippocampal dependent behavior. Synapse 64:742-753.

Perrotti LI, Hadeishi Y, Ulery PG, Barrot M, Monteggia L, Duman RS, Nestler EJ (2004) Induction of $\delta$ FosB in reward-related brain structures after chronic stress. J Neurosci 24:10594-10602.

Perrotti LI, Weaver RR, Robison B, Renthal W, Maze I, Yazdani S, Elmore RG, Knapp DJ, Selley DE, Martin BR, Sim-Selley L, Bachtell RK, Self DW, Nestler EJ (2008) Distinct patterns of DeltaFosB induction in brain by drugs of abuse. Synapse 62:358-369.

Robbins TW, Ersche KD, Everitt BJ (2008) Drug addiction and the memory systems of the brain. Ann N Y Acad Sci 1141:1-21.

Robison AJ (2014) Emerging role of CaMKII in neuropsychiatric disease. Trends Neurosci 37:653-662.
Robison AJ, Nestler EJ (2011) Transcriptional and epigenetic mechanisms of addiction. Nat Rev Neurosci 12:623-637.

Robison AJ, Vialou V, Mazei-Robison M, Feng J, Kourrich S, Collins M, Wee S, Koob G, Turecki G, Neve R, Thomas M, Nestler EJ (2013) Behavioral and structural responses to chronic cocaine require a feedforward loop involving $\delta \mathrm{FosB}$ and calcium/calmodulin-dependent protein kinase II in the nucleus accumbens shell. J Neurosci 33:4295-4307.

Robison AJ, Vialou V, Sun HS, Labonte B, Golden SA, Dias C, Turecki G, Tamminga C, Russo S, Mazei-Robison M, Nestler EJ (2014) Fluoxetine epigenetically alters the CaMKII $\alpha$ promoter in nucleus accumbens to regulate $\delta$ FosB binding and antidepressant effects. Neuropsychopharmacology 39:1178-1186.

Spencer S, Scofield M, Kalivas PW (2016) The good and bad news about glutamate in drug addiction. J Psychopharmacol 30:1095-1098.

Srivas S, Thakur MK (2017) Epigenetic regulation of neuronal immediate early genes is associated with decline in their expression and memory consolidation in scopolamine-induced amnesic mice. Mol Neurobiol 54:5107-5119.

Sweatt JD (2013) The emerging field of neuroepigenetics. Neuron 80:624632.

Thompson AM, Gosnell BA, Wagner JJ (2002) Enhancement of long-term potentiation in the rat hippocampus following cocaine exposure. Neuropharmacology 42:1039-1042.

Ulery-Reynolds PG, Castillo MA, Vialou V, Russo SJ, Nestler EJ (2009) Phosphorylation of $\delta$ FosB mediates its stability in vivo. Neuroscience 158:369-372.

Vialou V, Robison AJ, Laplant QC, Covington HE 3rd, Dietz DM, Ohnishi YN, Mouzon E, Rush AJ 3rd, Watts EL, Wallace DL, Iñiguez SD, Ohnishi YH, Steiner MA, Warren BL, Krishnan V, Bolaños CA, Neve RL, Ghose S, Berton O, Tamminga CA, et al. (2010) $\delta$ FosB in brain reward circuits mediates resilience to stress and antidepressant responses. Nat Neurosci 13:745-752.

Vialou V, Thibault M, Kaska S, Cooper S, Gajewski P, Eagle A, Mazei-Robison M, Nestler EJ, Robison AJ (2015) Differential induction of FosB isoforms throughout the brain by fluoxetine and chronic stress. Neuropharmacology 99:28-37.

Vorel SR, Liu X, Hayes RJ, Spector JA, Gardner EL (2001) Relapse to cocaine-seeking after hippocampal theta burst stimulation. Science 292:1175-1178

Walker DM, Cates HM, Heller EA, Nestler EJ (2015) Regulation of chromatin states by drugs of abuse. Curr Opin Neurobiol 30:112-121.

Walton M, Henderson C, Mason-Parker S, Lawlor P, Abraham WC, Bilkey D, Dragunow M (1999) Immediate early gene transcription and synaptic modulation. J Neurosci Res 58:96-106.

Wang N, Ge F, Cui C, Li Y, Sun X, Sun L, Wang X, Liu S, Zhang H, Liu Y, Jia M, Yang M (2018) Role of glutamatergic projections from the ventral CA1 to infralimbic cortex in context-induced reinstatement of heroin seeking. Neuropsychopharmacology 43:1373-1384.

Xu C, Krabbe S, Gründemann J, Botta P, Fadok JP, Osakada F, Saur D, Grewe BF, Schnitzer MJ, Callaway EM, Lüthi A (2016) Distinct hippocampal pathways mediate dissociable roles of context in memory retrieval. Cell 167:961-972.e16.

Zhu H, Pleil KE, Urban DJ, Moy SS, Kash TL, Roth BL (2014) Chemogenetic inactivation of ventral hippocampal glutamatergic neurons disrupts consolidation of contextual fear memory. Neuropsychopharmacology 39:1880-1892.

Zornoza T, Cano-Cebrián MJ, Martínez-García F, Polache A, Granero L (2005) Hippocampal dopamine receptors modulate cFos expression in the rat nucleus accumbens evoked by chemical stimulation of the ventral hippocampus. Neuropharmacology 49:1067-1076. 